\title{
SARANA AKOMODASI SEBAGAI PENUNJANG KEPARIWISATAAN DI JAWA BARAT
}

\section{Oleh: Wahyu Eridiana*)}

\begin{abstract}
Abstrak
Jawa Barat adalah salah satu propinsi di Indonesia yang memiliki kekayaan obyek wisata cukup banyak dan beragam; obyek wisata alam, wisata budaya dan wisata belanja terdapat di propinsi ini. Pada hari-hari libur menjadi fenomena social tersendiri, kendaraan pribadi, bus-bus wisata dari luar maupun dari dalam propinsi memadati obyek-obyek wisata di berbagai tempat. Demikian pula wisatawan yang memanfaatkan fasilitas akomodasi (hotel dan penginapan) menjadi lebih ramai bersamaan dengan suasana liburan tersebut. Pada tahun 2005 wisatawan manca Negara dan wisatawan nusantara yang memanfaatkan jasa akomodasi di Jawa Barat sebesar 7.237.059 orang dan dapat dilayani oleh 1.278 usaha akomodasi. Rata-rata tingkat hunian kamar yaitu sebesar $37 \%$ nya untuk hotel berbintang dan $32 \%$ nya untuk jasa akomodasi lainnya. Tamu manca Negara sebagian besar menginap di hotel-hotel berbintang dan meka rata-rata menginap selama 3 hari, sedangkan tamu nusantara (domestic) sebagian besar menginap di jasa akomodasi lainnya dan lama menginap rata-rata 1,3 hari. Seluruh wisatawan tersebut sampai saat ini dapat dilayani oleh fasilitas akomodasi yang ada.
\end{abstract}

Kata kunci: sarana akomodasi, kepariwisataan.

*) Drs. Wahyu Eridiana, M.Si., adalah dosen Jurusan Pendidikan Geografi FPIPS UPI. 


\section{Pendahuluan}

Unsur terpenting didalam kepariwisataan selain obyek wisata yang menjadi tujuan utama wisatawan adalah sarana akomodasi, sebagai tempat untuk beristirahat atau menginap di daerah tujuan wisata. Macam-macam tempat menginap tersebut diantaranya hotel, penginapan dan pondok wisata. Untuk memperjelas pembahasan selanjutnya, baiklah sarana akomodasi di atas secara konseptual kita jelaskan berikut ini.

Hotel adalah suatu usaha yang menggunakan bangunan yang disediakan secara khusus, dimana setiap orang dapat menginap, makan, memperoleh pelayanan dan menggunakan fasilitas lainnya dengan pembayaran. Ciri khusus dari hotel adalah mempunyai restoran yang dikelola langsung dibawah manajemen hotel tersebut.

Hotel, ada yang termasuk kategori hotel berbintang dan ada hotel melati. Hotel berbintang adalah usaha yang menggunakan suatu bangunan atau sebagian bangunan yang dsediakan secara khusus, dan setiap orang dapat menginap, makan serta memperoleh pelayanan dan fasilitas lainnya dengan pembayaran dan telah memenuhi persyaratan sebagai hotel berbintang seperti yang telah ditentukan oleh dinas pariwisata daerah.

Adapun hotel melati adalah usaha yang menggunakan suatu bangunan atau sebagian bangunan yang disediakan secara khusus, dimana setiap orang dapat menginap, makan serta memperoleh pelayanan fasilitas lainnya dengan pembayaran dan belum memenuhi persyaratan sebagai hotel berbintang tetapi telah memenuhi kriteria sebagai hotel melati yang dikeluarkan oleh dinas pariwisata daerah.

Penginapan adalah usaha jasa pelayanan penginapan sebagai akomodasi dalam rangka kegiatan pariwisata dengan tujuan untuk rekreasi, memperluas pengetahuan dan pengalaman serta tujuan lainnya. Pondok wisata adalah usaha jasa pelayanan penginapan bagi umum yang dilakukan perorangan dengan menggunakan sebagian atau seluruh dari tempat tinggalnya (dengan pembayaran harian).

Keseluruhan akomodasi diatas, adalah salah satu dari sejumlah kebutuhan yang diperlukan oleh orang yang sedang melaksanakan perjalanan wisata.

\section{Wisatawan dan Pariwisata}

Wisatawan (tourist), menurut Unietd Nation Conference on Travel and Tourism adalah setiap orang yang mengunjungi negara yang bukan merupakan tempat tinggalnya, untuk berbagai tujuan, tetapi bukan untuk mencari pekerjaan atau penghidupan dari negara yang dikunjungi. Menurut W.T.O. seseorang dikatakan sebagai tourist apabila dari visitor yang menghabiskan waktu paling tidak satu malam (24) jam didaerah yang dikunjungi. Sedangkan visitor itu sendiri diartikan orang yang melakukan perjalanan ke daerah yang bukan merupakan tempat tinggalnya kurang dari 12 bulan dan tujuan perjalanan bukanlah untuk terlibat dalam kegiatan untuk mencari nafkah, pendapatan atau penghidupan ditempat tujuan.

Bagaimana dengan pariwisata (tourism), menurut Murphy, pariwisata adalah keseluruhan dari elemen-elemen terkait (wisatawan, daerah tujuan wisata, perjalanan, industri dan lain-lain) yang merupakan akibat dari perjalanan wisata ke daerah tujuan wisata, sepanjang perjalanan tersebut tidak permanen. 
Jadi sesuatu kegiatan dapat digolongkan kepada pariwisata jika sekurangkurangnya menyangkut tiga hal utama, sebagaimana dikemukakan Richardson, ketiga hal tersebut adalah :

a. adanya unsur perjalanan yaitu pergerakan manusia dari satu tempat ke tempat lainnya.

b. adanya unsur tinggal sementara ditempat yang bukan merupakan tempat tinggal yang biasanya.

c. tujuan utama dari pergerakan manusia tersebut bukan untuk mencari penghidupan/pekerjaan di tempat yang dituju.

\section{Perkembangan Kepariwisataan di Indonesia}

Jejak kepariwisataan di Indonesia telah ada sejak jaman penjajahan Belanda, yang dirintis oleh oerang-orang Belanda. Kepariwisataan pada jaman itu bernama Vereeniging Teoristen Verheer (VTV) yang kurang lebih berdiri pada tahun 1910, di Batavia. Kemudian pada tahun 1926, muncul usaha pariwisata bernama Lislind (Lissome Lindeman) yang 2 tahun kemudian berubah menjadi Nitour (Nederlandsche Indische Touristen Bureau).

Setelah kemerdekaan Indonesia yaitu pada tahun 1946, pemerintah membentuk lembaga kepariwisataan yang diberinama Honet (Hotel National and Tourism). Kemudian 9 tahun berikutnya ada Natour dan Yayasan Tourisme Indoneisa (Y.T.I.). Kongres-kongres kepariwisataan dilakukan pada tahun-tahun berikutnya, pada kongres tersebut, melahirkan konsep pariwisata yang diartikan untuk wisata inetrnasional (International Tourism) dan darmawisata (domestic tourism) untuk wisatawan dalam negeri.

Minat masyarakat dunia untuk berwisata ke Indonesia terus meningkat. Hal ini dapat dilihat dari terus bertambahnya jumlah wisatawan mancanegara datang untuk berlibur di negeri kita ini. Menurut Pitana \& Gayatri, perkembangan kunjungan wisatawan mancanegara tercatat sebagai berikut:

\begin{tabular}{|l|l|}
\hline \multicolumn{1}{|c|}{ Tahun kunjungan } & \multicolumn{1}{|c|}{ Jumlah wisatawan } \\
\hline 1966 & 20.000 \\
1968 & 86.000 \\
1970 & 129.000 \\
1974 & 313.452 \\
1978 & 486.674 \\
1997 & 5.180 .000 \\
2001 & 5.150 .000 \\
\hline
\end{tabular}

Semakin bertambah besarnya kunjungan wisata terebut, tentu secara ekonomis akan semakin bertambah besar juga bagi penerimaan devisa negara maupun terhadap masyarakat negara kita ini. Bagi penerimaan negara (devisa) dari sumber industri pariwisata menurut Pitana dan Gayatri adalah sebagai berikut:

\begin{tabular}{|l|l|}
\hline \multicolumn{1}{|c|}{ Tahun } & Jumlah Penerimaan \\
\hline 1984 & US\$ 519.7 juta \\
1988 & US\$ 1.194.1 juta \\
1990 & US\$ 1.890 .0 juta \\
\hline
\end{tabular}


Terjadinya penurunan penerimaan devisa pada tahun 2004 yang lalu, hal tersebut berkaitan dengan situasi keamanan di negara kita yang sedang terganggu, yaitu tragedi Kuta di Bali, tragedy Mariot di Jakarta dan isu wabah flu burung. Adapun bagi masyarakat secara langsung dapat memperluas lapangan kerja, baik yang bekerja di bidang usaha wisata maupun diluar wisata seperti menyediakan barang-barang untuk cindera mata atau makanan.

Berangkat dari gambaran perkembangan wisata tersebut, adalah suatu yang wajar bila pemerintah Indonesia tertarik untuk menjadikan pariwisata sebagai salah satu andalan bagi sumber penerimaan devisa bagi negara, karena :

Pertama, potensi sumber daya alam yang dapat dimanfaatkan untuk dijadikan obyek-obyek wisata baik yang menyangkut sumberdaya alam maupun sosial budaya cukup berlimpah di berbagai tempat, dengan keunikan tersendiri. Sekarang yang perlu dipikirkan selanjutnya adalah bagaimana memberdayakan potensi-potensi tersebut supaya bisa menjadi obyek-obyek yang layak jual bagi para wisatawan. Kedua, dengan semakin majunya peradaban dunia yang menjadikan banyak orang semakin terikat oleh pekerjaan dan terbatasnya waktu luang, kondisi seperti ini dapat melahirkan suatu kejenuhan dalam rutinitas kegiatan kesehariannya, maka tindakan refreshing/pemulihan kesegaran psikis menjadi suatu kebutuhan atau solusi yang tepat. Pergi berwisata ke berbagai tempat ketika mendapatkan liburan menjadi pilihan utamanya. Sehubungan dengan hal tersebut obyek-obyek wisata harus cukup tersedia dan memenuhi persyaratan psikologis bagi para pengguna obyek wisata tersebut. Ketiga, saat ini sarana perhubungan yang dapat memperlancar orang untuk berinteraksi baik antar persona maupun antar wilayah semakin baik (pelayanan, kecepatan maupun kemudahannya) sehingga jarak antar tempat tidak menjadi faktor penghalang yang kuat dalam melakukan suatu perjalanan. Keempat, dengan semakin membaiknya tingkat kehidupan masyarakat dunia maupun dinegara kita khususnya, menandakan potensi orang untuk berwisata (wisatawan manca negara \& domestik) semakin bertambah besar.

Untuk memenuhi berbagai kebutuhan dalam berwisata tersebut, maka sarana penunjang dalam bentuk akomodasi harus ditingkatkan pula baik kuantitas maupun kualitasnya, agar sarana pendukung tersebut turut berperan dalam memuaskan masyarakat ketika sedang melakukan perjalanan wisatanya.

\section{Usaha Akomodasi dan Penggunanya di Jawa Barat}

a. Usaha Akomodasi di Indonesia

Di Indonesia pada tahun 2006, usaha yang bergerak dibidang akomodasi tercatat sebesar 11.461 buah. Jumlah kamar yang dapat digunakan oleh para wisatawan dan lainnya sebanyak 285.530 buah kamar. Dari jumlah pengusaha akomodasi di atas, sebesar $9.22 \%$ adalah hotel berbintang dengan jumlah kamar sebanyak 106.692 buah. Sedangkan jumlah akomodasi diluar hotel berbintang ada 10.404 buah dengan jumlah kamar sebanyak 178.838 buah.

Hotel berbintang diklasifikasikan ke dalam lima tingkatan: hotel berbintang satu, berbintang dua, berbintang tiga, berbintang empat dan berbintang lima. 
Adapun jumlah masing-masing tingkat hotel tersebut, menurut Badan Pusat Statistik tahun 2006, adalah sebagai berikut :

- Hotel bintang 1 ada 303 usaha

- Hotel bintang 2 ada 241 usaha

- Hotel bintang 3 ada 265 usaha

- Hotel bintang 4 ada 165 usaha

- Hotel bintang 5 ada 83 usaha

Hotel-hotel melati dan jasa akomodasi lainnya adalah sebagai berikut :

- hotel melati ada 5.878 buah

- di luar hotel melati ada 2.279 buah

Dari sejumlah akomodasi di atas, sebanyak $12.35 \%$ terdapat di Jawa Barat.

b. Usaha Akomodasi dan Penggunanya di Jawa Barat

Dalam bidang pariwisata jumlah pengunjung/wisatawan merupakan sumber dari segala kemajuan sektor ini, suatu obyek wisata akan berkembang apabila wisatawan yang datang ke obyek-obyek wisata dalam jumlah besar dan berkesinambungan. Sebaliknya jika yang datang dalam jumlah yang kecil serta tidak berkelanjutan, maka suatu obyek wisata akan mendapat kesulitan untuk berkembang. Oleh karena itu agar para wisatawan biasa datang berulangkali (tidak bosan) ke obyek-obyek wisata dan memanfaatkan segala fasilitasnya, maka kesan terhadap obyek wisata harus ditanggapi positif. Kesan positif dari suatu obyek wisata maupun terhadap segala macam fasilitas wisata, kecenderungan wisatawan untuk mengulangi datang lebih besar. Bahkan pengaruh kesan positif tersebut tidak hanya untuk yang pernah merasakannya tetapi lebih jauh bisa memberi informasi kepada yang lainnya atau mengajak yang lainnya, ini berarti kesan positif sama dengan suatu peluang yang baik.

Di Indonesia, selain propinsi Bali sebagai tujuan wisata utama manca negara maupun domestik diantaranya adalah Propinsi Jawa Barat. Untuk melayani wisatawan tersebut sarana akomodasi di Jawa Barat harus dapat mencukupinya, karena jumlah tamu yang memerlukan pelayanan akomodasi di Jawa Barat terus menunjukan peningkatan yang luar biasa. Pada tahun 2001 tamu manca negara dan nusantara berjumlah 4.026.141 orang dan pada tahun 2005 menjadi 7.139 .603 orang, yang berarti terjadi peningkatan sebesar $77.3 \%$ selama 5 tahun tersebut.

Dilihat dari jumlah pengguna jasa akomodasi yang terus meningkat tersebut, maka suatu hal yang perlu diperhatikan oleh setiap pengelola akomodasi adalah optimalisasi pelayanan. Karena sifat usaha ini adalah mengutamakan pelayanan. Jika pelayanan tidak sesuai dengan harapan para penggunanya, sudah bisa dipastikan para tamu tersebut tidak akan kembali menggunakan jasa yang pernah mengecewakannya itu. Jadi pelayanan yang baik bagi para pengelola akomodasi identik dengan keberlangsungan dan kemajuan usaha dibidang ini.

Di Jawa Barat usaha yang bergerak dibidang akomodasi pada tahun 2005 tercatat sebanyak 1.413 usaha, sebesar $9.55 \%$ adalah usaha hotel berbintang dan sebesar $90.45 \%$ adalah usaha akomodasi diluar hotel berbintang. Hotel berbintang yang paling banyak di Jawa Barat adalah hotel berbintang 4 yaitu ada 45 buah, dan hotel berbintang 3 sebanyak 44 buah dan 46 buah hotel lainnya yang terdiri dari hotel berbintang satu dan lima. Jumlah kamar yang terdapat di hotel 
berbintang satu sampai lima tersebut sebanyak 11.682 buah kamar atau sebesar $30.3 \%$ dari seluruh jumlah kamar yang terdapat di propinsi ini. Adapun jumlah usaha akomodasi diluar hotel berbintang di Jawa Barat ada 1.278 buah. Dari jumlah usaha tersebut terdapat 26.904 buah kamar atau sebesar $69.70 \%$ nya dan jumlah penggunanya mengalami penurunan.

Menurut catatan Biro Pusat Statistik Propinsi Jawa Barat, tamu yang memanfaatkan jasa akomodasi di propinsi ini tahun 2005 mengalami penurunan sebesar $10.4 \%$ dibandingkan dengan tahun 2004. Penurunan terjadi pada tamu tamu domestik (Nusantara), sedangkan tamu dari manca negara ada kenaikan. Tamu nusantara sebagian besar memanfaatkan jasa akomodasi diluar hotel berbintang, tetapi tamu manca negara sebagian besar yaitu $86 \%$ nya memanfaatkan jasa akomodasi hotel- hotel berbintang. Adanya penurunan tamu yang memanfaatkan jasa penginapan terebut di Jawa Barat, berdasarkan para pengamat ada kaitannya dengan terjadinya musibah yang disebabkan oleh bencana alam di beberapa tempat, seperti bencana tsunami yang memporak porandakan beberapa kawasan wisata pantai, dan menelan korban jiwa dalam jumlah banyak. Dampak psikologis seperti ketakutan akibat bencana itu dapat mempengaruhi calon wisatawan untuk mengurungkan datang ke obyek-obyek wisata terutama ke wisata pantai. Hal semacam ini berimbas terhadap penurunan tamu yang memanfaatkan jasa akomodasi penginapan terutama sangat dirasakan sekali oleh para pemilik jasa akomodasi yang berada di kawasan pantai khususnya. Diharapkan kejadian penurunan tidak terlalu lama dan segera pulih sebagaimana biasanya agar obyek-obyek wisata dan jasa akomodasi kembali normal dan para wisatawan dapat memanfaatkan kembali jasa-jasa tersebut.

Bagi para pengusaha jasa akomodasi, selain jumlah pengguna juga lama menggunakan jasa yang disediakannya adalah sama pentingnya. Di Jawa Barat rata-rata tamu yang menggunakan jasa akomodasi pada tahun 2005 adalah sebagai berikut :

- tamu manca Negara rata-rata menginap 3 hari

- tamu nusantara rata-rata menginap 1,3 hari

Bila dihubungkan bahwa tamu-tamu yang menggunakan jasa akomodasi tersebut mayoritasnya adalah wisatawan, maka di Jawa Barat tamu dari manca negara yang berwisata di daerah ini rata-rata 3 hari dan 1 hari adalah wisatawan nusantara. Rata-rata tingkat hunian kamarnya untuk hotel berbintang sebesar 37 $\%$ nya dan di luar hotel berbintang $32 \%$ nya. Berdasarkan angka tersebut maka di Jawa Barat fasilitas akomodasi untuk para wisatawan sangat memadai.

\section{Penutup}

Obyek wisata dan segala fasilitasnya suatu yang tidak bisa terpisahkan, jika salah satunya tidak memenuhi maka kepariwisataan tidak akan berkembang secara baik. Jawa barat adalah salah satu propinsi yang memiliki obyek wisata alam yang cukup kaya dan sekaligus sebagai obyek wisata belanja, khususnya di kota Bandung. Demikian pula fasilitas akomodasi yang cukup memadai hal itu adalah suatu modal besar yang perlu dipertahankan, bahkan lebih dikembangkan lagi. Maka sector kepariwisataan di Jawa Barat suatu saat bisa dijadikan sebagai sumber penerimaan pendapat daerah yang cukup handal. Sehubungan dengan hal itu pengembangan obyek-obyek wisata di berbagai tempat, pengembangan sumber daya manusia yang akan bertanggung jawab dalam mengelola obyek- 
obyek wisata serta peningkatan pelayanan dalam berbagai fasilitas yang berkaitan dengan kepariwisataan tersebut, harus menjadi model pengembangan yang serasi dan seimbang, agar kepariwisataan dapat menjadi modal pembangunan di propinsi ini.

\section{Daftar Pustaka}

BPS 2001-2005, Statistik Hotel dan Akomodasi di Jawa Barat, Provinsi Jawa Barat.

BPS 2006, Statistik Hotel dan Akomodasi lainnya di Indonesia, Jakarta Indonesia. Pitana I Gde, 2005, Sosiologi Pariwisata, Yogyakarta: Andi.

Clare A. Gunn, 1994. Tourism Planning. Basics, Concepts, Cases. Third Edition. Taylor \& Francis Publisher.

Linberg, K. (2002). The Economic Impacts of Ecotourism. Available On-line: http://ecotour.csu.edu.auecotour/marl.htm. Downloaded on 3/25/02

Lumsdon, L. (1997). Tourism Marketing. Boston USA : International Thomson Business Press 